\title{
Association of Serum Vitamin D Level and Vitamin D Receptor Polymorphism (Apa 1) and Breast Cancer
}

\author{
BELAL A.E. MONTASER, M.D.*; SUZY F. GOHAR, M.D.**; SUZAN A. AL-HASSANIN, M.D.** and \\ SHAIMAA S. SOLIMAN, M.D.*** \\ The Departments of Clinical Pathology*, Clinical Oncology \& Nuclear Medicine** and Public Health \& Community Medicine***, \\ Faculty of Medicine, Menoufia University, Shebin El-Kom, Egypt
}

\begin{abstract}
Background: The active form of Vitamin D is thought to be protective against breast cancer. The activity of this steroid hormone is mediated mainly through the Vitamin D Receptor (VDR).

Aim of Study: The aim of the current study was to assess the possible association between serum Vitamin D level together with Apa1 receptor polymorphism and breast cancer.

Patients and Methods: This study was conducted at Clinical Oncology and Clinical Pathology Departments, Menoufia University. A total of 114 participants were included. Vitamin D levels and Apa1 polymorphism were assessed in both patients and healthy controls.

Results: Mean serum Vitamin D levels were significantly higher among normal controls compared to cancer patients $(31.54 \pm 4.57$ versus $14.12 \pm 1.43)$ respectively ( $p$-value $<0.001)$. In relation to Apa1 gene polymorphism the serum Vitamin D levels were significantly associated with AA and AC genotypes ( $p$-value $<0.001)$ and both of these genotypes were prevalent in breast cancer compared to CC genotype. Low Vitamin D levels and AC genotypes were significantly related to Her 2 positive disease.

Conclusion: Testing the effect of varying genotypes and Vitamin D levels on the function of the VDR could help to improve future testing and treatment of woman at risk for breast cancer.
\end{abstract}

Key Words: Vitamin D-Breast cancer-Risk-Vitamin D receptor-Apa 1 - Polymorphism.

\section{Introduction}

THE active form of Vitamin D (1, 25-dihydroxyvitamin $\mathrm{D}$ ) has been demonstrated to promote cell differentiation and inhibit cell proliferation and affect cancer risk via binding to Vitamin D Receptor (VDR) [1]

Correspondence to: Dr. Belal A.E. Montaser, E-Mail: drbelalmontaser@yahoo.com
There is inverse association between $25(\mathrm{OH})$ $\mathrm{D}$ and risk of cancer and normal Vitamin D level is essential for prevention cancer [2].

Synthesis of 1, 25-dihydroxyvitamin D in breast tissue may also contribute to maintenance of normal cell function, which could be impaired in Vitamin D deficiency [3].

Nuclear receptors which are activated by the steroid hormones like estrogen and progesterone are critical regulators of mammary gland development and have complex roles in breast cancer etiology [4].

The Vitamin D Receptor (VDR) is a member of the nuclear receptor family which is highly expressed in breast tissue, is activated by its hormonal ligand 1, 25-dihydroxyvitamin D $(1,25 \mathrm{D})$ [4].

Several Single Nucleotide Polymorphisms (SNP) have been described in the VDR gene, and some SNPs are associated with tumor development [5].

Most of the functional sequence variants that identified near the 3 'region of VDR gene were Bsm1, Apa1 and Taq1 SNP [6].

These SNPs are in disequilibrium with each other and are located in the same haplotype block. Hence, these SNPs may have the potential to influence the mRNA stability [6].

ApaI (rs7975232), TaqI (rs731236), BsmI (rs1544410) and FokI (rs10735810) are functional VDR SNPs that affect VDR gene expression and mRNA stability [7]. 
The VDR polymorphism case-control studies showed different associations between different VDR polymorphisms and risk of breast cancer in different populations but it was reported that The ApaI SNP found in intron 8 confers was the most frequent polymorphism in Egyptian women [8,9].

The aim of the current study was to assess the relation between serum Vitamin D level and ApaI SNP polymorphism and breast cancer and to find their relation with the clinical features of the patients and pathological features of the disease.

\section{Patients and Methods}

This case control study was conducted at Clinical Oncology and Clinical Pathology Departments, in Faculty of Medicine, Menoufia University.

A total of 60 patients with confirmed pathological diagnosis of breast cancers who attend to the new cases clinic of Clinical Oncology Department were recruited for the study from September 2017 to March 2018.

Patients with associated major co-morbidities, undergoing current hemodialysis, elevated liver enzymes, primary hyperparathyroidism, hypercalcemia, hypercalciuria, or Paget's disease and on Vitamin D supplement, with personal history of cancer other than breast cancer, presented with recurrent disease or received previous anticancer treatment were excluded from the study.

Also 54 apparently age matched apparently normal females were included as a control group.

Written informed-consents were provided by all participants and accredited by our Ethical Committee.

All patients included in the study were completely evaluated by: Complete history and physical examination and full investigations in the form of laboratory studies as Complete Blood Count (CBC), complete renal and liver functions and tumor markers in cases of metastatic disease.

And radiological investigations (bilateral mammography, chest X-ray, abdomino-pelvic ultrasound, and computed tomography of chest, abdomen and pelvis in case of metastatic disease).

All patients were staged based on TNM staging system.
DNA was extracted from whole blood from all cases. Serum levels of Vitamin D were assayed using the commercially available ELISA kit.

PCR- RFLP was done to determine the distribution of allele and genotype frequencies of the Apa-1 C/A polymorphism in Vitamin D Receptor (VDR) gene.

\section{- Sampling:}

Under complete aseptic conditions, $4 \mathrm{ml}$ of venous blood were collected and divided as follows: Tube A, $2 \mathrm{ml}$ of blood collected in EDTA (to prevent clotting and DNA degradation) for DNA extraction and kept immediately at $-20^{\circ} \mathrm{C}$. Tube $\mathrm{B}, 2 \mathrm{ml}$ were collected, left to clot and serum was separated and used for CA-15.3 and serum Vitamin D assay. vitamin D levels less than $20 \mathrm{~g} / \mathrm{dl}$ were considered low.

\section{- Laboratory investigations:}

Serum CA-15.3 were done by VIDAS systems (bioMérieux, Marcy l'Etoile, France) which is an automated Enzyme-Linked Fluorescent Immunoassay (ELFA) based on a one-step immunoassay sandwich method and a final fluorescent detection step for the quantitative measurements. Serum level of 25-OH Vit.D was assayed using the commercially available Competitive ELISA kit (EUROIMMUNAG-Seekamp31-23560 Luebeck, Germany) following manufacturer instructions [10] [11].

Molecular testing and polymorphism analysis

DNA extraction: Total DNA was extracted from EDTA treated blood samples using Thermo Scientific GeneJET Genomic DNA Purification Kit (Thermo Fisher Scientific, MA, USA). Whole blood samples were digested with Proteinase $\mathrm{K}$ in the Lysis Solution. The lysate is then mixed with ethanol and loaded on the purification column where the DNA binds to the silica membrane. Impurities are effectively removed by washing the column with the prepared wash buffers. Genomic DNA is then eluted under low ionic strength conditions with the Elution Buffer. The eluted genomic DNA was kept immediately at $-20^{\circ} \mathrm{C}$ till subjected to PCR.

\section{Polymerase chain reaction:}

The 745 base pair (bp) fragment encompassing the $\mathrm{C}$ to A polymorphic site in Apa-1 Vitamin D receptor gene region was amplified using the amplification mix which consisted of:

- 1 Leach of primers (25 gM), forward primer in exon 8 (5'-CAGAGCATGGACAGGGAGC- 
AA) and a reverse primer in exon 9 (5'GCAACTCCTCATGGCTGAGGTCTC) were used, 12.5 Lofeam Taq Green PCR master mix (Thermo Fisher Scientific, MA, USA), 5.5 of nuclease-free Water, Then 5 Lofextracted DNA was added to the corresponding reaction tube

\section{PCR cycling conditions:}

The PCR amplification was performed on preprogrammed thermal cycler (Perkin Elmer GeneAmp PCR System 2400 Thermal Cycler) under the following conditions: An initial denaturation step at $95^{\circ} \mathrm{C}$ for $2 \mathrm{~min}$, followed by 40 cycles, each cycle consisted of denaturation at $94^{\circ} \mathrm{C}$ for 45 seconds, annealing at $67^{\circ} \mathrm{C}$ for 45 seconds and extension at $72^{\circ} \mathrm{C}$ for 60 seconds. Final extension at $72^{\circ} \mathrm{C}$ for $2 \mathrm{~min}$ was carried out.

\section{Confirmation of successful PCR amplification:}

Agarose gelelectrophoresis (2\% agarose gel is prepared by dissolving $1 \mathrm{gm}$ of agarose powder in $50 \mathrm{ml}$ Tris-Borate-EDTA (TBE) buffer $(0.5 \mathrm{X})$ was boiled, then 3 Letidium bromides were added and the gel was then poured in a mould to solidify. Five Lof normal range (100bp) ladder and 10 of PCR product were applied. Then electrophoresis was done for 20 minutes at 150 volt. Detection of positive bands is confirmed by detecting specific bands which correspond to ladder specific band of $745 \mathrm{bp}$ for ApaI gene amplification visualized under ultraviolet-light.

\section{Statistical analysis:}

Data was analyzed by SPSS V 23 (SPSS Inc. Released 2015. IBM SPSS statistics for windows, Version 23.0, Armnok, NY: IBM Corp.). Student's $t$-test is a test of significance used for comparison of quantitative variables between two groups of normally distributed data, while Mann Whitney's test was used for comparison of quantitative variables between two groups of not normally distributed data. Chi-square test $\left(\chi^{2}\right)$ was used to study association between qualitative variables. Whenever any of the expected cells were less than five, Fischer's Exact test was used. Z-test was used to compare two proportions in two groups. Two sided $p$-value of $<0.05$ was considered statistically significant. Hradt Weinberg principle: If the $p$-value is less than 0.05 then it implies there is a deviation if it is $>0.05$ then no issues.

\section{Results}

This case control study was conducted in Clinical Oncology Department in collaboration with
Clinical Pathology Department at Faculty of Medicine, Menoufia University.

A total of 60 patients of pathologically proved breast cancer and 54 apparently healthy age matched females were included in the study.

As summarized in (Table 1) there was no difference in mean age and body mass index and menopausal status between both cases and controls.

Strikingly mean serum Vitamin D levels were significantly higher among normal controls compared to cancer patients $31.54 \pm 4.57$ versus $14.12 \pm$ 1.43 respectively ( $p$-value $<0.001$ (Table 1 ).

Table (1): Epidemiological features of the patients and control.

\begin{tabular}{|c|c|c|c|c|}
\hline & $\begin{array}{c}\text { Breast cancer } \\
(n=60) \\
\text { Mean } \pm S D\end{array}$ & $\begin{array}{c}\text { Controls } \\
(n=54) \\
\text { Mean } \pm \text { SD }\end{array}$ & $\begin{array}{c}t- \\
\text { test }\end{array}$ & $\begin{array}{c}p- \\
\text { value }\end{array}$ \\
\hline Age & $52.13 \pm 5.75$ & $51.59 \pm 4.26$ & 0.56 & 0.57 \\
\hline \multirow[t]{2}{*}{ BMI } & $30.89 \pm 9.44$ & $31.18 \pm 9.73$ & 0.16 & 0.87 \\
\hline & No. $(\%)$ & No. $(\%)$ & $x^{2}$ & $p$-value \\
\hline \multicolumn{5}{|c|}{ Menopausal status: } \\
\hline Pre & $30(50.0)$ & $32(59.3)$ & 0.98 & 0.32 \\
\hline Post & $30(50.0)$ & $22(40.7)$ & & \\
\hline \multicolumn{5}{|l|}{ Vitamin D: } \\
\hline Normal & $0(0.0)$ & $54(100.0)$ & 114 & $<0.001$ \\
\hline Low & $60(100.0)$ & $\begin{array}{ll}0 & (0.0)\end{array}$ & & \\
\hline \multicolumn{5}{|l|}{ BMI categories: } \\
\hline Underweight & $6 \quad(10.0)$ & $6 \quad(11.1)$ & 1.92 & 0.85 \\
\hline Normal & $6 \quad(10.0)$ & $4 \quad(7.4)$ & & \\
\hline Overweight & $22(36.7)$ & $16(29.6)$ & & \\
\hline Obese I & $10(16.7)$ & $14(25.9)$ & & \\
\hline Obese II & $10(16.7)$ & $8 \quad(14.8)$ & & \\
\hline Obese III & $6 \quad(10.0)$ & $6 \quad(11.1)$ & & \\
\hline
\end{tabular}

All breast cancer patients had low Vitamin D levels while all healthy controls had normal Vitamin $\mathrm{D}$ level and this difference was also significant ( $p$ value $<0.001$ ).

Regarding Apa 1 gene polymorphism the A allele was more common among patients (74\% of patients) with breast cancer compared to normal controls ( $12 \%$ of control, $p$-value $<0.001)$ (Table 2).

The most common genotypes of Apa 1 genes among patients was the AA and AC genotypes (40\% and $43.3 \%$ respectively, $p$-value $<0.001$ ), while, the CC genotype was the most common genotype among normal controls (85.2\% of healthy controls, $p$-value <0.001) (Table 2).

Participant's with AC gene has 29.90 (8.52; 104.92) and participants with AA has 27.6 (7.83; 97.32) times risk of developing breast cancer than CC. also, participants with A allele has 12.87 (6.37; 
26.02) times risk of developing breast cancer than participants without (Table 2).

Table (2): Association of genotypic and allelic frequencies and risk of breast cancer.

\begin{tabular}{cccccl}
\hline & $\begin{array}{c}\text { Breast } \\
\text { cancer } \\
(\mathrm{n}=60) \\
\text { Mean } \pm \text { SD }\end{array}$ & $\begin{array}{c}\text { Controls } \\
(\mathrm{n}=54) \\
\text { Mean } \pm \mathrm{SD}\end{array}$ & $\chi^{2}$ & $\begin{array}{c}p- \\
\text { value }\end{array}$ & $\begin{array}{c}\text { OR } \\
(95 \% \mathrm{CI})\end{array}$ \\
\hline Genotype: & & & & & \\
CC & $10(16.7)$ & $46(85.2)$ & 53.39 & $\mathrm{Z} 1<0.001$ & OR1 *29.90 \\
AC & $26(43.3)$ & $4(7.4)$ & & $\mathrm{Z} 2<0.001$ & OR2*27.6 \\
AA & $24(40.0)$ & $4(7.4)$ & & $\mathrm{Z} 3<0.001$ & $(7.83 ; 97.32)$ \\
Alleles: & & & & & \\
C allele & $46(38.3)$ & $96(88.9)$ & 59.71 & $<0.001$ & OR 12.87 \\
A allele & $74(61.7)$ & $12(11.1)$ & & & $(6.37 ; 26.02)$ \\
\hline
\end{tabular}

*: $\mathrm{CC}$ is the reference.

- $\mathrm{Z} 1$ for comparing the percentage of $\mathrm{CC}$ between breast cancer and controls.

- Z2 for comparing the percentage of CA between breast cancer and controls.

- Z3 for comparing the percentage of AA between breast cancer and controls.

OR1: AC in patients versus controls

OR2: AA in patients versus controls.

Regarding the risk of low Vitamin D, the risk of developing low Vitamin D is lower in subjects with $\mathrm{CC}$ genotype than subjects with AC genotype and AA genotype by $97 \%$ and $96 \%$ respectively (Table 3).

Table (3): Relation between Apa1 gene and risk of low serum Vitamin D levels among all participants.

\begin{tabular}{lcccc}
\hline & \multicolumn{2}{c}{ Vitamin D } & $\begin{array}{c}p- \\
\text { value }\end{array}$ & $\begin{array}{c}\text { OR } \\
(95 \% \text { CI })\end{array}$ \\
\cline { 2 - 3 } & Low & Normal & & \\
\hline GG & $10(16.7)$ & $46(85.2)$ & $<0.001$ & OR1*29.90 (8.52;104.92) \\
AC & $26(43.3)$ & $4(7.4)$ & & OR2 *27.6 (7.83;97.32) \\
AA & $24(40.0)$ & $4(7.4)$ & & \\
\hline
\end{tabular}

*: $\mathrm{CC}$ is the reference genotype.

OR1: AC low versus normal.

OR2: AA low versus normal.

Among all participants, low Vitamin D level was significantly associated with AA and AC genotypes ( $p$-value $<0.001)$ (Table 4$)$.

Table (4): Relation between Vitamin D mean levels and genes among all participants.

\begin{tabular}{|c|c|c|c|c|c|c|}
\hline $\begin{array}{l}\text { Geno- } \\
\text { type }\end{array}$ & $\begin{array}{c}\text { Breast } \\
\text { cancer } \\
\text { Mean } \pm S D\end{array}$ & $\begin{array}{c}p- \\
\text { value }\end{array}$ & Post Hoc & $\begin{array}{c}\text { Normal } \\
\text { c patients } \\
\text { Mean } \pm S D\end{array}$ & $\begin{array}{c}p- \\
\text { value }\end{array}$ & Post Hoc \\
\hline $\mathrm{ACC}$ & $15.26 \pm 1.01$ & $<0.001$ & $p 10.31$ & $32.94 \pm 3.32$ & 0.008 & $p 1<0.001$ \\
\hline $\mathrm{AC}$ & $14.90 \pm 1.08$ & & $p 2<0.001$ & $22.70 \pm 0.23$ & & $p 2<0.001$ \\
\hline $\mathrm{AA}$ & $12.80 \pm 0.73$ & & $p 3<0.001$ & $24.35 \pm 1.09$ & & $p 30.46$ \\
\hline
\end{tabular}

There was no significant relation between serum Vitamin D level and patients age while, patients with morbid obesity (grade II and III) had significantly lower Vitamin D levels compared to others (Table 5).
Table (5): Relation between mean serum Vitamin D levels among cancer patients and patients and disease features.

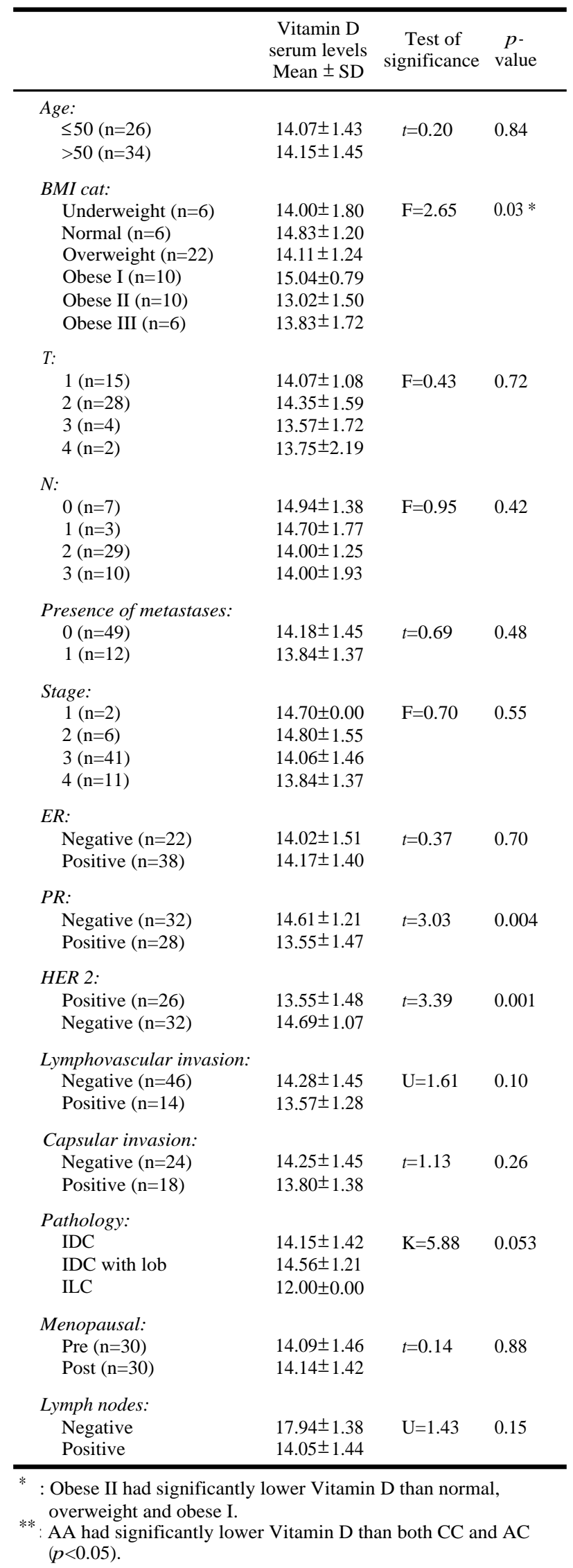


Although low serum Vitamin D levels were observed in patients with larger tumor size, lymph node involvement, advanced stage, metastatic disease, also in patients with capsular and lymphovascular invasion, however, these relations were not statistically significant (Table 5).

Vitamin D levels were significantly lower in patients with Her 2 positive disease and progesterone positive tumors ( $p$-value: 0.001 and 0.004 respectively) (Table 5).

In relation to Apa1 gene, patients with AA genotypes had significantly lower mean serum Vitamin D levels $(12.80 \pm 0.73$ and $p$-value $<0.001)$ (Table 5).

The most prevalent genotype among cancer patients was AC genotype representing (43\% of all patients) followed by AA genotype representing (40\% of all patients).

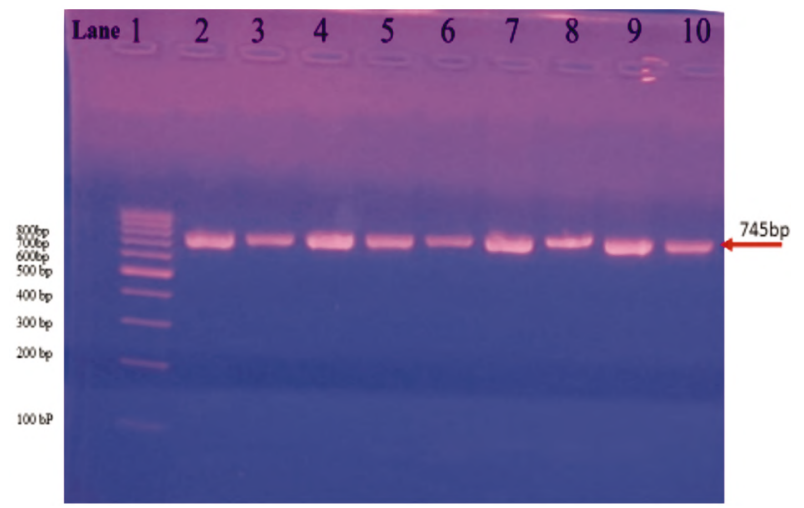

Fig. (1): Arepresentative agarose gel picture showing Apa-I Vitamin D receptor gene amplification bands of 745bp (lanes 2-10) and lane 1 correspond to 100bp DNA ladder.

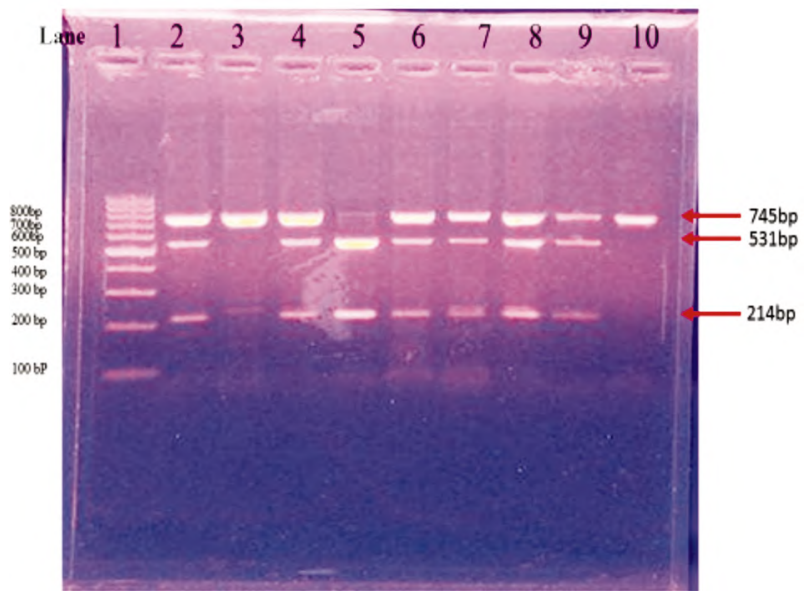

Fig. (2): A representative agarose gel picture showing PCRRFLP analysis of Apa-I genotypes in genomic DNA of study subjects with restriction endonuclease enzyme Apa-I. Lane 1 100-bp DNA ladder, lane 2, 4, $6,7,8$ and 9 C/A heterozygous $(745,531$ and $214 \mathrm{bp}$ bands), lane $5 \mathrm{C} / \mathrm{C}$ homozygous (531 and 214bp bands) and lane 3 and 10 A/A homozygous (745bp).
There was no significant relation between different genotypes and tumor size, lymph node involvement and metastatic disease however most of patients with stage III disease had AC and AA genotypes and most patients with metastatic disease had AA genotype (Table 6).

The AC genotype was significantly associated with PR negative, Her2 positive disease, lymphovascular and capsular invasion (Table 6).

Table (6): Relation between Apa 1 gene and epidemiological and clinical features in cancer patients.

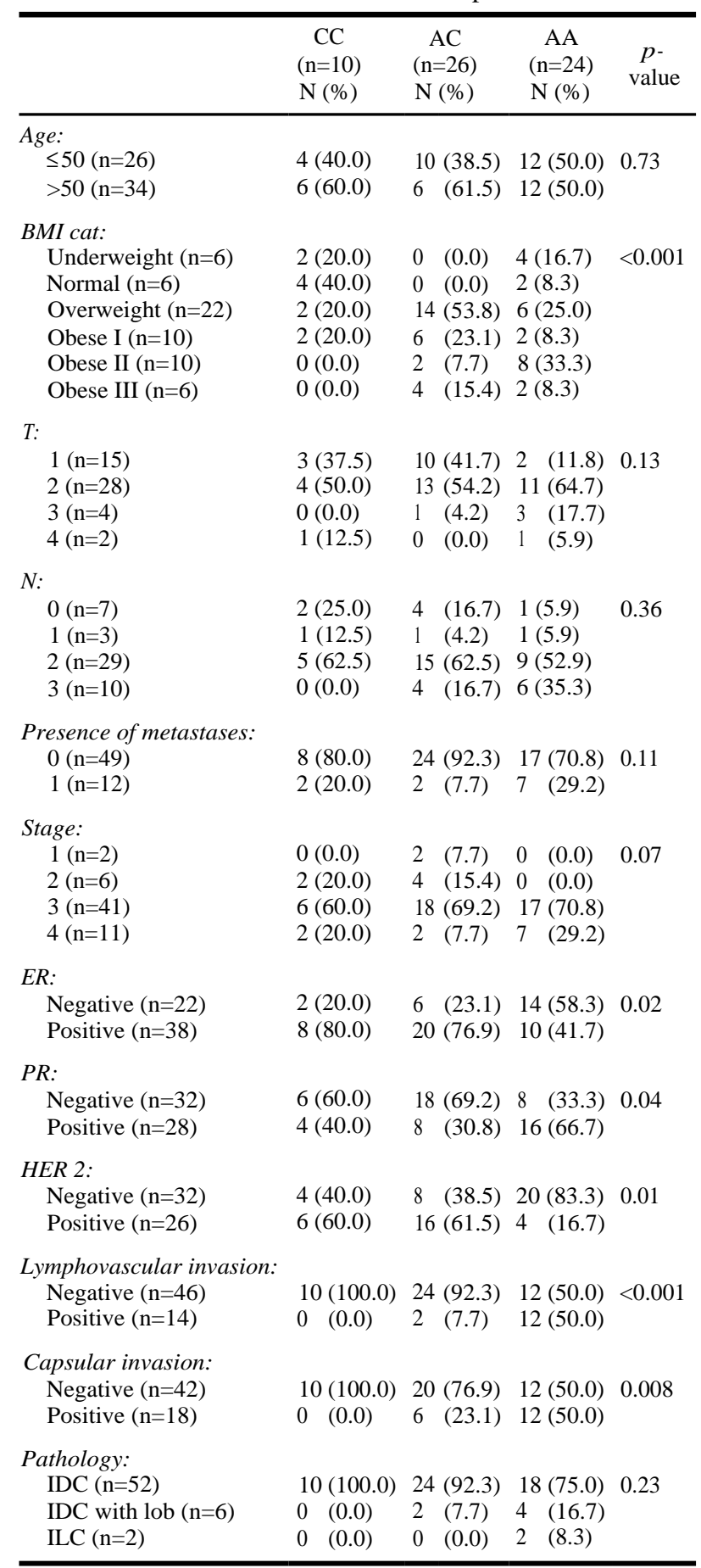




\section{Discussion}

It is well known that breast cancer is strongly affected by the hormonal environment. Genetic variations affecting hormonal activity are possible contributors for increased risk of breast cancer [12]

Common allelic variants have been identified in human VDR gene with some of them having an essential risk for a variety of diseases including breast cancer [12] .

The active hormone 1,25(OH)2D3 can induce a cascade of gene regulation and signaling molecules by binding to VDR [4].

The active metabolite of Vitamin D, 1,25dihydroxycholecalciferol $(1,25(\mathrm{OH}) 2 \mathrm{D} 3)$ can suppress cell proliferation in cancer [13].

A total of 114 participants were recruited in the study 60 patients with confirmed diagnosis of breast cancer and 54 apparently normal females as control group.

Both groups were age matched there were no significant difference between them regarding menopausal status and body mass index.

The frequency of low Vitamin D level in patients with breast cancer was significantly higher as compared to the controls as $100 \%$ of the patients have low serum Vitamin D serum levels $(<20 \mathrm{ng} / \mathrm{dl})$ and all the controls had normal Vitamin D levels with mean values $14.12 \pm 1.43$ and $31.54 \pm 4.57$ respectively.

These results were comparable to that of Sofi et al., Elzehery et al., Atoum and Al-Khatib, Imtiaz et al., Abo Elsoud et al., Basharat et al., and $\mathrm{Wu}$ et al., who reported the same significant difference between patients and healthy controls [3,12,14-18]

These relations indicate the possible role of low Vitamin D as predisposing factor for breast cancer. As low circulating levels of $25(\mathrm{OH})$ Vitamin $\mathrm{D}$ is supposed to decrease the local production of $1,25(\mathrm{OH}) 2 \mathrm{D}$ within the breast tissues and increase the risk of breast cancer [19]

The relation between Vitamin D receptor Apa 1 polymorphism was investigated it was found that the A allele was significantly more frequent among patients. Participants with A allele has 12.87 (6.37; 26.02) times risk of developing breast cancer than participants without.

Regarding genotypic variations, participant's with AC gene has $29.90(8.52 ; 104.92)$ and partic- ipants with AA has $27.6(7.83 ; 97.32)$ times risk of developing breast cancer than CC. So the CC genotype was considered the most protective genotype against breast cancer risk.

Also, Curran et al., found a significant increased risk of breast cancer with ApaI AC and CC genotypes [20].

Our results are against that reported by AbdElsalam et al., who conversely reported that the $\mathrm{C}$ allele was the frequent allele in patients and consequently found that significant increased risk of breast cancer was detected among women carrying ApaI CC genotype compared with women carrying genotype AA. And did not found any associated risk with $\mathrm{AC}$ genotypes [21].

No significant association between the ApaI polymorphisms and breast cancer risk were observed by McCullough et al., and Mishra et al., $[22,23]$

The conflict between the results may be due to different geographical distributions of selected participants. And difference in sample size may have an impact on results.

This difference could be also related to the difference in the features of the included participant for example in Abd El-Salam and her colleagues restricted their analysis to post-menopausal women aged between 50 and 70 years old while our study included both pre and post-menopausal women and Vitamin D and calcium levels could be influenced by menopausal status [21].

McKay and his colleagues reported that environmental factors, such as diet, contribute to modified associations between the genotype and breast cancer as calcium and Vitamin D metabolism can affects cell proliferation and differentiation of several cancer cell lines in vitro [24].

To explore the direct relation between Apa 1 polymorphism and Vitamin D level we found that AC and AA genotypes were associated with the risk of low Vitamin D while the CC genotype was the protective gene against low Vitamin $\mathrm{D}$. The lowest Vitamin D levels were associated with AA genotype.

Consequently the most common genotypes among patients were the AC followed by the AA genotype.

To explore the impact of low Vitamin D levels in breast cancer patients, patients' epidemiological and clinical features were studied. 
Patients with grade II and III obesity had significantly lower Vitamin D level this finding is going with that of Vashi et al who reported that obese cancer patients (BMI $>=30 \mathrm{~kg} / \mathrm{m}^{2}$ ) had significantly lower levels of serum Vitamin $\mathrm{D}$ as compared to non-obese patients (BMI $<30$ $\mathrm{kg} / \mathrm{m}^{2}$ ) [25]

Also El-Shorbagy et al., and Alco et al., reported that low Vitamin D level is related to high BMI [26,27]

In the current study, the serum Vitamin D levels were lower in patients with larger tumor size, lymph node involvement, in patients with capsular and lympho-vascular invasion, advanced stage, metastatic disease although our results were not significant but it was comparable to that of ElShorbagy et al., Ismail et al., and Thanasitthichai et al., who reported significant negative relation between Vitamin D level and advanced stage and lymph node involvement [26,28,29]

Also El-Zehery et al., and El-Shorbagy et al., reported the significant relation between serum Vitamin D and presence of metastases $[\mathbf{1 2 , 2 6}$. And Hatse et al., shows positive correlation between low Vitamin D level and larger tumor size [30].

On the other hand Imtiaz et al., and Wu et al., did not find positive correlation between low $\mathrm{Vi}$ tamin D level and high tumor grade and advanced stage and this was against our results $[15,18]$

In relation to hormone receptors ER and PR there was positive correlation between low Vitamin D levels and PR positive and Her 2 positive tumors while, there was no significant relation between serum Vitamin D and ER status of the tumor.

Although it was identified that high serum levels of Vitamin D may reduce serum progesterone and estradiol [31]. The association between vitamin $D$ levels and hormone receptor expression in breast cancer tissue was controversial. As Imtiaz et al., and Abo El-Soud et al., did not find significant relation between receptor status and serum Vitamin D levels while Kim et al., reported poorer outcomes of Vitamin D deficient patients with luminal type breast cancer in Korean patients $[\mathbf{1 5 , 1 6 , 3 2 ]}$.

On the other hand Ismail et al., reported that there is no significant relation between ER and PR receptors expression and Vitamin D levels while confirmed the significant relation between Her2 positive tumor and low Vitamin D level in a group of Egyptian population [15]. While Yao et al., found that low Vitamin D is associated with ER negative tumors in African American patients [33].

The authors think that these controversies regarding receptor expression may be related to tumor aggressiveness, may be racial and ethnic variations rather than to low Vitamin D level.

Collectively, our findings suggest possible relation between Vitamin D level and some poor prognostic features in breast cancer.

Regarding the relation with patient features, The AC genotype was significantly associated with PR negative, Her2 positive disease, lymphovascular and capsular invasion. While the AA genotype was the most common genotype in patients with metastatic disease this suggests their poor prognostic impact.

\section{Conclusion:}

In the current study all patients with breast cancer had low Vitamin D levels. VDR Apa1 polymorphisms (AC and $\mathrm{CC}$ genotypes) are associated with both breast cancer and low Vitamin D level risks. Also both low Vitamin D levels and AC and AA genotypes are associated with some poor prognostic features as Her2 positive disease lymphovascular and capsular invasion suggesting possible poor prognostic features.

Authors recommend that Vitamin D level and Vitamin D receptor status should be assessed for all breast cancer patients and those who are at high risk for breast cancer and Vitamin D supplement should be provided for them.

\section{References}

1- KRISHNAN A.V. and FELDMAN D.: Mechanisms of the anti-cancer and anti-inflammatory actions of Vitamin D. Annu. Rev. Pharmacol. Toxicol., 51: 311-36, 2011.

2- McDONNELL S.L., BAGGERLY C., FRENCH C.B., BAGGERLY L.L., GARLAND C.F., GORHAM E.D., et al.: Serum 25-hydroxyvitamin D concentrations 40ng/ml are associated with $>65 \%$ Lower Cancer Risk: Pooled analysis of randomized trial and prospective cohort study. PLoS One, 11. e0152441, 2016.

3- SOFI N.Y., JAINA M., KAPILB U., SEENUC V., KAMALD V.K. and PANDEY R.M.: Nutritional risk factors and status of serum $25(\mathrm{OH}) \mathrm{D}$ levels in patients with breast cancer: A case control study in India. Journal of Steroid Biochemistry \& Molecular Biology, 175: 559, 2018.

4- WELSH J.: Function of the Vitamin D endocrine system in mammary gland and breast cancer. Molecular and Cellular Endocrinology, 453: 88-95, 2017.

5- YAO X., ZENG H., ZHANG G., ZHOU W., YAN Q., DAI L. and WANG X.: The Associated Ion between the 
VDR Gene Polymorphisms and Susceptibility to Hepatocellular Carcinoma and the Clinicopathological Features in Subjects Infected with HBV. BioMed Research International. Volume, Article ID 953974, 8 pages. http:// dx.doi.org/ 10.1155/2013/953974, 2013.

6- FANG Y., VAN MEURS J.B., D'ALESIO A., JHAMAI M., ZHAO H., RIVADENEIRA F., et al.: Promoter and 3 -untranslated-region haplotypes in the Vitamin D receptor gene predispose to osteoporotic fracture: The rotterdam study. American Journal of Human Genetics, 77 (5): $807-$ 23, 2005.

7- ALKHAYAL K.A., AWADALIA Z.H., VAALI-MOHAMMED M.A., AL-OBEED O.A., AL-WESAIMER A., HALWANI R., et al.: Association of Vitamin D Receptor Gene Polymorphisms with Colorectal Cancer in a Saudi Arabian Population. PLoS ONE, 11 (6): e0155236. doi:10.1371/journal.pone.0155236, 2016.

8- SIMON-GRUITA A., DUTA G., CONSTANTIN N., POJOGA M.D., SAITAN T. and STOIAN V.: Apa I and Taq I polymorphisms of VDR (Vitamin D receptor) gene in association with susceptibility to tuberculosis in the Romanian population. Romanian Biotechnological Letters, Vol. 18, No. 1, 2013.

9- ATOUM M. and ALZOUGHOOL F.: Vitamin D and Breast Cancer: Latest Evidence and Future Steps. Breast Cancer: Basic and Clinical Research 2017. Volume 11: 1-8 (C) The Author(s) 2017.

10- GRÖBER U., SPITZ J., REICHRATH J., KISTERS K. and HOLICK M.F.: Vitamin D: Update 2013 From rickets prophylaxis to general preventive healthcare. Dermatoendocrinol, 5 (3): 331-47, 2013.

11- LOPES N., SOUSA B., MARTINS D., GOMES M., VIEIRA D., VERONESE L.A., et al.: Alterations in Vitamin D signaling and metabolic pathways in breast cancer progression: A study of VDR, CYP27B1 and CYP24A1 expression in benign and malignant breast lesions. B.M.C. Cancer, 10: 483, 2010.

12- ELZEHERY R., BAIOMY A., HEGAZY M., FARES R., EL-GILANY A. and HEGAZI R.: Vitamin D status, receptor gene BsmI (A/G) polymorphism and breast cancer in a group of Egyptian females. The Egyptian Journal of Medical Human Genetics, 18: 269-73, 2017.

13- THORNE J. and CAMPBELL M.J.: The Vitamin D receptor in cancer. Proc. Nutr. Soc., May, 67 (2): 115-27. doi: 10.1017/S0029665108006964, 2008.

14-ATOUM M.F. and AL-KHATIB Y.M.: Association between Serum 25-hydroxy Vitamin D Concentration and TaqI Vitamin D Receptor Gene Polymorphism among Jordanian Females with Breast Cancer. Chin. Med. J., 130: 1074 8, 2017.

15- IMTIAZ S., SIDDIQUI N. and MUHAMMAD A.: Vitamin $D$ deficiency in newly diagnosed breast cancer patients. Indian J. Endocrinol. Metab., 16 (3): 409-13, 2012.

16- ABO ELSOUD M., ABU SIYAM A., DEMIAN S. and MERSAL B.: Study of relationship between vitamin d receptor gene polymorphism expression (BSM-I \& FOKI), serum levels of vitamin $d$ and the risk of breast cancer in Egyptian females; correlation with the clinicopathological features of the disease. International Journal of Basic and Applied Medical Sciences ISSN: 2277-2103 (Online). Vol. 6 (2) May-August, pp. 89-99, 2016.

17- BASHARAT I., ZIA N., MURAD F., MALIK A.Z. and MAHMOOD N.: Vitamin D Deficiency as a Risk Factor of Breast Cancer. Journal of Rawalpindi Medical College (JRMC), 18 (2): 199-201, 2014.

18- WU Y., SARKISSYAN M., CLAYTON S., CHLEBOWSKI R. and VADGAMA J.: Association of Vitamin D3 Level with Breast Cancer Risk and Prognosis in African-American and Hispanic Women. Cancers, 9, 144; doi: 10.3390/cancers9100144, 2017.

19- HEWISON M., ZEHNDER D., CHAKRAVERTY R. and ADAMS J.S.: Vitamin D and barrier function: A novel role for extra-renal 1a-hydroxylase. Mol. Cell Endocrinol., 215: 31-8, 2004.

20- CURRAN J.E., VAUGHAN T., LEA R.A., WEINSTEIN S.R., MORRISON N.A. and GRIFFITHS L.R.: Association of a Vitamin D receptor polymorphism with sporadic breast cancer development. Int. J. Cancer, 83: 723-6, 1999.

21- ABD-ELSALAM E., ISMAEIL N. and ABD-ALSALAM H.: Vitamin D receptor gene polymorphisms and breast cancer risk among postmenopausal Egyptian women. Tumor. Biol., 36: 6425-31. Doi 10.1007/s13277-0153332-3, 2015.

22- McCULLOUGH M.L., STEVENS V.L., DIVER W.R., FEIGELSON H.S., RODRIGUEZ C., BOSTICK R.M., et al.: Vitamin D pathway gene polymorphisms, calcium intake, and risk of postmenopausal breast cancer. Breast Cancer Res., 9 (1): R9, 2007.

23- MISHRA D.K., WU Y., SARKISSYAN M., SARKISSYAN S., CHEN Z., SHANG X., et al.: Vitamin D receptor gene polymorphisms and prognosis of breast cancer among African-American and hispanic women. PLoS One, 8 (3): e57967, 2013.

24- McKAY J.D., McCULLOUGH M.L., ZIEGLER R.G., KRAFT P., SALTZMAN B.S., RIBOLI E., et al.: Vitamin $D$ receptor polymorphisms and breast cancer risk: Results from the national cancer institute breast and prostate cancer cohort consortium. Cancer Epidemiol Biomarkers Prev., 18: 297-305, 2009.

25- VASHI P., LAMMERSFELD C., BRAUN D. and GUPTA D.: Serum 25-hydroxyvitamin D is inversely associated with body mass index in cancer. Nutrition Journal, 10: 51, http://www.nutritionj.com/content/10/1/51, 2011.

26- EL-SHORBAGY S., HAGGAG R., EBIAN H., LABIB H. and HARB O.: Prognostic Impact of 25-Hydroxyvitamin D Levels in Egyptian Patients with Breast Cancer. J. Cancer Sci. Ther., 9: 6. Doi: 10.4172/1948-5956. 1000466, 2017.

27- ALCO G., IGDEM S., DINCER M., OZMEN V., SAGLAM S., SELAMOGLU D., et al.: Vitamin D Levels in Patients with Breast Cancer: Importance of Dressing Style. Asian Pacific Journal of Cancer Prevention, Vol. 15. Doi: http://dx.doi.org/10.7314/APJCP.2014.15.3.1357, 2014.

28- ISMAIL A., EL-AWADY R., MOHAMED G., HUSSEIN M. and SHIMAA R.: Prognostic Significance of Serum Vitamin D Levels in Egyptian Females with Breast Cancer. Asian Pac. J. Cancer Prev., 19 (2): 571-6. 
29- THANASITTHICHAI S., CHAIWERAWATTANA A. and PRASITTHIPAYONG A.: Association of Vitamin D Level with Clinicopathological Features in Breast Cancer. Asian Pac. J. Cancer Prev., 16 (12): 4881-3.

30- HATSE S., LAMBRECHTS D., VERSTUYF A., SMEETS A., BROUWERS B., VANDORPE T., et al.: Vitamin D status at breast cancer diagnosis: Correlation with tumor characteristics, disease outcome, and genetic determinants of Vitamin D insufficiency. Carcinogenesis Vol. 33 No.7 pp. 1319-26. Doi: 10.1093/carcin/bgs 187, 2012.

31- KNIGHT J., WONG J., BLACKMORE K., RABOUD J. and VIETH R.: Vitamin D association with estradiol and progesterone in young women. Cancer Causes Control, 21: 479-83, Doi 10.1007/s10552-009-9466-0, 2010.

32- KIM H.J., LEE Y.M., KO B.S., LEE J.W., YU J.H., SON B.H., et al.: Vitamin D deficiency is correlated with poor outcomes in patients with luminal type breast cancer. Ann. Surg. Oncol., 18: 1830-6, 2011.

33- YAO S., ZIRPOLI G., BOVBJERG D., JANDORF L., HONG C.C., ZHAO H., et al.: Variants in the Vitamin D pathway, serum levels of Vitamin D, and estrogen receptor negative breast cancer among African-American women: A case-control study. Breast Cancer Research, 14: R58. http://breast-cancer-research.com/content/14/2/R58, 2012

\title{
الإرتباط بين مستوى فيتامين د فى مصل الدم وتعدد الآثكال

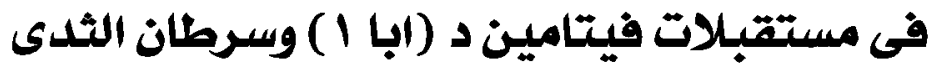

\author{
الخذلفة: يعتقد آن الشكل الفعال لفيتامين (د) يكون وقائيا ضد سرطان الثىى. يقوم هذا الهرمون بلدده بشكل رئيسى من خلال مستقبل \\ فيتامين د (VDR). \\ الهدف من البحث: إن الهدف من هذه الدراسة هو تقييم العلاقة المحتملة بين مستوى فيتامين د فى مصل الدم جنبا إلى جنب مع تعدد

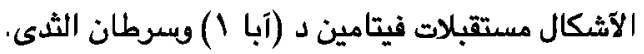

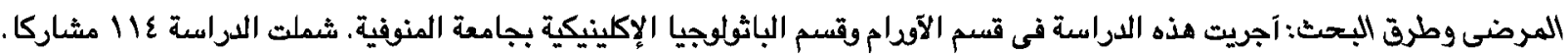

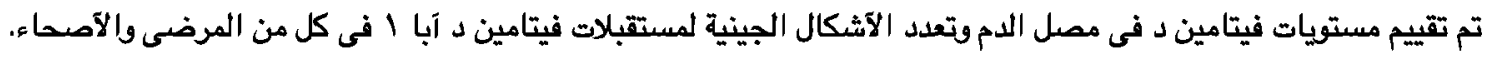

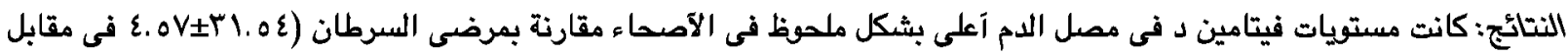

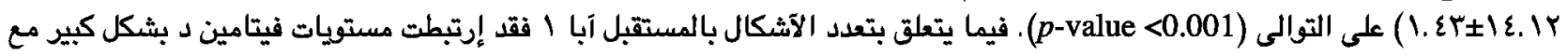

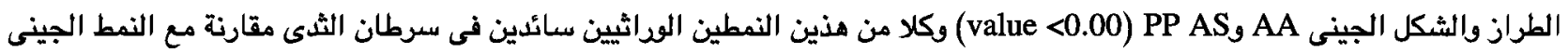

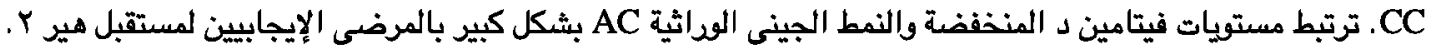

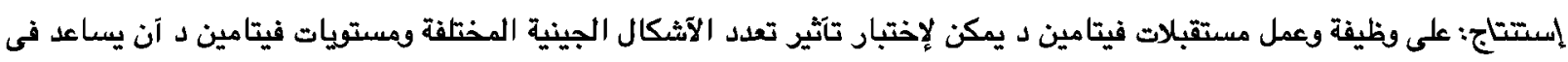

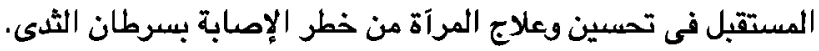

